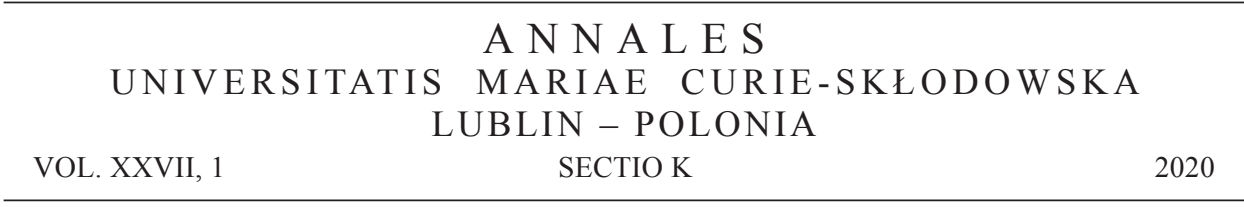

Uniwersytet Marii Curie-Skłodowskiej w Lublinie, Wydział Politologii i Dziennikarstwa

\author{
MICHAŁ HARKOT
}

ORCID ID: https://orcid.org/0000-0001-8434-3147

\title{
Wpływ wahabizmu na pozycję społeczno-polityczna Arabii Saudyjskiej
}

Impact of Wahhabism on the socio-political position of Saudi Arabia

\begin{abstract}
ABSTRAKT
Celem artykułu jest określenie roli wahabizmu dla współczesnej pozycji Arabii Saudyjskiej w wymiarach społecznym oraz politycznym. W związku z powyższym, weryfikacji poddano trzy hipotezy badawcze. Pierwsza z nich zakłada, że słabnąca pozycja Imperium Osmańskiego na przełomie XIX i XX wieku oraz sojusz z rodziną Saudów były głównymi elementami, które wpłynęły na rozwój ruchu wahabickiego w Arabii Saudyjskiej. Po drugie, w wyniku bliskich powiązań z rodziną Saudów, ruch wahabicki odgrywa współcześnie decydującą rolę w kreowaniu społeczno-politycznej pozycji Arabii Saudyjskiej. Po trzecie, wahabizm wspiera rozwój organizacji terrorystycznych o charakterze salafickim z powodu bliskości religijno-politycznej.

Główny wniosek niniejszej pracy zawiera się w stwierdzeniu, że ruch wahabistyczny odgrywa decydującą rolę w kreowaniu życia społecznego Arabii Saudyjskiej oraz dąży do religijnej ekspansji w regionie Bliskiego Wschodu, między innymi za pośrednictwem powiązań z salafickimi organizacjami terrorystycznymi. W artykule przedstawiono ponadto genezę wahabizmu oraz główne założenia doktrynalne.

Chcąc zilustrować wykorzystany warsztat metodologiczny, należy wymienić metodę case study, za pomocą której scharakteryzowano powiązania arabskiego wahabizmu z salafickimi organizacjami terrorystycznymi (w odniesieniu do Al-Kaidy oraz Państwa Islamskiego). W celu właściwego przedstawienia wpływu wahabizmu na pozycję społeczno-polityczną Arabii Saudyjskiej, w pracy wykorzystano też założenia wywodzące się z nurtu realizmu neoklasycznego.
\end{abstract}

Slowa kluczowe: wahabizm, Arabia Saudyjska, terroryzm, islam 


\section{WSTĘP}

Celem niniejszego artykułu jest analiza wpływu ruchu wahabickiego na współczesną pozycję Arabii Saudyjskiej w wymiarze społeczno-politycznym. Chcąc uchwycić istotę tego zagadnienia, w pracy postawiono trzy następujące pytania badawcze. Po pierwsze, co było główną przyczyną rozwoju ruchu wahabickiego w Arabii Saudyjskiej? Po drugie, jaki jest wpływ wahabizmu na współczesną pozycję społeczno-polityczną Arabii Saudyjskiej? Po trzecie, czy wahabizm jest powiązany z rozwojem terroryzmu na Bliskim Wschodzie? W związku z powyższym, weryfikacji poddano trzy hipotezy badawcze. Pierwsza z nich zakłada, że słabnąca pozycja Imperium Osmańskiego na przełomie XIX i XX wieku oraz sojusz z rodziną Saudów były głównymi elementami, które wpłynęły na rozwój ruchu wahabickiego w Arabii Saudyjskiej. Po drugie, w wyniku bliskich powiązań z rodziną Saudów ruch wahabicki odgrywa współcześnie decydującą rolę w kreowaniu społeczno-politycznej pozycji Arabii Saudyjskiej. Po trzecie, wahabizm wspiera rozwój organizacji terrorystycznych o charakterze salafickim z powodu bliskości religijno-politycznej.

W celu właściwego przedstawienia wpływu wahabizmu na pozycję społeczno-polityczną Arabii Saudyjskiej, w pracy wykorzystano założenia wywodzące się z nurtu realizmu neoklasycznego. Istnieją trzy powody, dla których posłużenie się powyższym paradygmatem uznano w pracy za właściwe. Po pierwsze, zwolennicy tego nurtu uważają, że analiza polityki danego państwa nie może odnosić się wyłącznie do struktury systemu międzynarodowego. Innymi słowy kształt polityki państwa jest również wynikiem oddziaływania czynników o charakterze wewnętrznym, na przykład ideologii, ambicji przywódców czy też poziomu kontroli nad społeczeństwem. Po drugie, nurt realizmu neoklasycznego za cel państwa uznaje maksymalizację wpływu (przez utrzymanie statusu quo lub politykę rewizjonistyczną). Po trzecie, przedstawiciele tego paradygmatu uważają, że warsztat metodologiczny powinien odnosić się do metod jakościowych, szczególnie do analizy przypadku i śledzenia procesów [Czaputowicz 2014: 33-37]. Według autora, trzy wymienione „argumenty” korespondują z istotą niniejszej pracy. Po pierwsze bowiem, analizie poddana zostanie pozycja najwyższych przedstawicieli ruchu wahabickiego, którzy jako „czynnik wewnątrzpaństwowy” posiadają obok dynastii Saudów największe znaczenie polityczne w Arabii Saudyjskiej. Po drugie, w pracy przedstawione zostaną dążenia ruchu wahabickiego do maksymalizacji swoich wpływów na poziomie państwowym oraz międzynarodowym (polityka rewizjonistyczna). Po trzecie, zgodnie z nurtem realizmu neoklasycznego warsztat metodologiczny zostanie oparty w pracy na analizie przypadków ${ }^{1}$.

Struktura artykułu składa się ze wstępu, opisu genezy wahabizmu, założeń doktrynalnych, współczesnej roli, jaką wahabizm odgrywa dla społeczno-politycznej

1 Wśród najważniejszych przedstawicieli realizmu neoklasycznego znajdują się takie osoby, jak William C. Wohlforth, Thomas Christensen, Randall Schweller oraz Fared Zakaria. Zob. też: [Kaczmarski 2015]. 
pozycji Arabii Saudyjskiej, powiązań z salafickimi organizacjami terrorystycznymi oraz zakończenia. Problematyka ruchu wahabickiego z powodu swojego marginalnego znaczenia w skali całego islamu nie należy do najważniejszych zagadnień dla badaczy zajmujących się bezpieczeństwem Bliskiego Wschodu. Dlatego podjęcie tej tematyki jest zasadne z naukowego punktu widzenia (tym bardziej że pozycja Arabii Saudyjskiej w regionie Bliskiego Wschodu ulega obecnie znaczącej redefinicji).

\section{GENEZA WAHABIZMU}

Powstanie oraz rozwój ruchu wahabickiego, będącego współcześnie dominującą doktryną religijną w Arabii Saudyjskiej, w sposób nierozerwalny związane są z osobą Muhammada Ibn Abd al-Wahhaba. Założyciel tegoż ruchu urodził się w osadzie Al-Ujajna w Nadżdzie (centralnej prowincji współczesnej Arabii Saudyjskiej) w 1703 r. Pochodził z dobrze wykształconej rodziny o silnych korzeniach prawniczych oraz teologicznych. Muhammad Ibn Abd al-Wahhab przejawiał zbliżone zainteresowania zawodowe - podobno już w wieku dziesięciu lat znał na pamięć całą treść Koranu oraz ukończył podstawową naukę arabskiego [Delong-Bas 2004: 17-18]. Dążąc do uzyskania zawodu sędziego i kaznodziei, Muhammad Ibn Abd al-Wahhab w pierwszych latach swojej edukacji związał się ze środowiskami naukowymi w Mekce i Medynie. W późniejszym okresie pobierał również nauki w Al-Basrze, mieście położonym na najważniejszym szlaku handlowym w regionie. Stanowiło ono również miejsce pierwszego politycznego wystąpienia Muhammada Ibn Abd al-Wahhaba, podczas którego skrytykował muzułmańską moralność oraz uznał wiarę w jedynobóstwo ( $i$ 'alan at-tauhid) za dogmat religijny (sprzeciwiając się politeizmowi praktykowanemu w niektórych częściach regionu Półwyspu Arabskiego). W ciągu następnych lat Muhammad Ibn Abd al-Wahhab osiadał również w kilku innych miastach, jednak jego nauki spotykały się z wyraźnym sprzeciwem ze strony lokalnych społeczności [Zdanowski 2004: 9-10].

Przełomowym wydarzeniem okazało się spotkanie Muhammada Ibn Abd al-Wahhaba w 1744 r. na terenie dzisiejszego Rijadu z przywódcą lokalnego klanu - Ibn Saudem. Bliskość ideologiczna, jak również świadomość potencjalnych korzyści skłoniły obie strony do zawarcia ścisłego sojuszu, który ostatecznie został przypieczętowany małżeństwem Ibn Sauda z córką Muhammada Ibn Abd al-Wahhaba. Stworzona w ten sposób dynastia saudyjsko-wahabicka miała w przyszłości stanowić główną siłę polityczną na Półwyspie Arabskim [Sozek 2005: 35].

W kolejnych latach ruch wahabicki przeżywał okres terytorialnego rozwoju. Pierwotnie objął on swoim zasięgiem centralną część Półwyspu Arabskiego, zdobywając z czasem wpływy również w Afryce Północnej, gdzie odpowiednikiem wahabizmu stała się sekta senusich, założona przez Muhammada Ibn Ali as-Sanusi'ego (struktury tej organizacji do dzisiaj są obecne na terytorium Libii oraz peryferiach Sahary). Główny cel ruchu religijnego odnosił się do wyzwolenia świata muzułmańskiego 
spod obcych wpływów oraz ukonstytuowania zjednoczonego imperium, funkcjonującego według ściśle przestrzeganych zasad islamu [Fryzeł 1974: 8].

Po śmierci Ibn Sauda jego następcą został Abdelaziz Ibn Saud, którego polityka kontynuacji w dalszym ciągu opierała się na bliskim sojuszu z ugrupowaniem Abd al-Wahhaba. W wyniku śmierci przywódcy wahabitów w 1792 r. i przejęcia władzy przez jego synów zapoczątkowana została dynastia al-Szajch (współcześnie obok rodziny Saudów jest to ród o największych wpływach w Arabii Saudyjskiej) [Bakalarz 2007: 9]. Wraz z końcem XVIII w. połączone siły Saudów oraz al-Szajchów zorganizowały wojenną kampanię, docierając do Bagdadu oraz opanowując terytorium ówczesnej Syrii. Następnie zjednoczone wojska wyruszyły do zachodniej części Arabii w kierunku Morza Czerwonego, zdobywając Tajf, Mekkę i Medynę. W 1802 r. saudyjsko-wahabickie oddziały zaatakowały terytorium współczesnego Iraku, profanując m.in. położony w Karbali grobowiec imama Husajna - wnuka Proroka, będącego jednym z najważniejszych świętych szyitów. Najazd ten, podobnie jak poprzednie kampanie odznaczał się niebywałą brutalnością - dokonywano masowych egzekucji, jak również dewastacji wszelkich form bogactwa oraz innowierstwa. Wojskowo-religijna ekspansja wzbudziła głębokie zaniepokojenie w politycznych kręgach Konstantynopola. Sułtan początkowo unikał otwartej konfrontacji, skupiając się w pierwszej kolejności na zagrożeniu ze strony obecnych w Egipcie wojsk Napoleona Bonapartego. Dopiero w 1812 r. wraz z wymarszem francuskich wojsk przeciwko Rosji otomański władca zdecydował się zdławić arabski bunt. Warto w tym miejscu dodać, że sułtan, pełniąc funkcję kalifa, a więc religijnego i politycznego następcy Proroka, sprawował symboliczną kontrolę nad Mekką i Medyną - świętymi miastami islamu. Zbrojne wystąpienie wahabitów stanowiło tym samym swoiste wyzwanie rzucone przeciwko jego autorytetowi. Otomański władca misję pokonania arabskich buntowników powierzył ówczesnemu rządcy Egiptu Muhammadowi Alemu. Wykonanie rozkazu sułtana zajęło ponad siedem lat - stolica Saudów została zdobyta bowiem dopiero w 1818 r. Dla wahabitów nastał wówczas okres okrutnych prześladowań. Przez resztę XIX w. Saudowie byli zmuszeni stopniowo odbudowywać swoją pozycję na Półwyspie Arabskim. W związku z powyższym dopiero w 1902 r. ówczesny przywódca klanu Abdelaziz Ibn Saud zdecydował się opuścić Kuwejt i powrócić z wygnania, rozpoczynając tym samym długoletnią kampanię zbrojnego odzyskiwania utraconych ziem. Jego determinacja przyczyniła się ostatecznie do proklamowania niepodległości Arabii Saudyjskiej we wrześniu 1932 r. [Marchand 2004: 26-28]. 


\section{DOKTRYNA WAHABIZMU}

Chcąc dokonać charakterystyki podstawowych założeń doktryny wahabizmu, w pierwszej kolejności należy zaznaczyć, iż edukacja Muhammada Ibn Abd al-Wahhaba, która w późniejszym okresie zaważyła na kontestacji poszczególnych założeń islamu, przebiegała w duchu tzw. szkoły hanbalickiej. Jej twórca Ahmed Ibn Hanbal (żyjący na przełomie VIII/IX w.) reprezentował bowiem najbardziej fundamentalną szkołę prawną w ówczesnej doktrynie sunnickiej. Uważał, że źródła późniejsze od Koranu i komentarzy Proroka nie posiadają jakiejkolwiek wartości prawnej. Można przypuszczać, że dążył on w ten sposób do wyrugowania wszelkich form egzegez oraz roli człowieka w kreowaniu religijno-politycznej rzeczywistości. Dla wyznawców szkoły hanbalickiej wszelki postęp winien dostosować się do Koranu, nie zaś odwrotnie. Muhammad Ibn Abd al-Wahhab w swoich założeniach odwoływał się przede wszystkim do poglądów hanbalickiego teologa Ibn Tajmijji, żyjącego na terytorium dzisiejszej Syrii na przełomie XIII/XIV w. [Marchand 2004: 23].

Muhammad Ibn Abd al-Wahhab swoje nauki opierał ponadto na: zakazie obejmowania kultem osób bądź też grobowców; zakazie wszelkich form wróżbiarstwa i szeroko pojętej magii; obowiązku pielgrzymki do Mekki; nakazie modlenia się pięć razy dziennie, postu oraz jałmużny; ograniczeniu noszenia jedwabnych ubrań oraz złotych ozdób; zakazie prostytucji i homoseksualizmu; potępieniu palenia tytoniu; zakazie krzywoprzysięstwa; zwalczaniu lichwiarstwa; zakazie śpiewania oraz grania na instrumentach muzycznych. Powyższe zasady z jednej strony nawiązywały do teologicznych podstaw islamu, $\mathrm{z}$ drugiej zaś akcentowały ascetyczny tryb życia, jaki mieli prowadzić wyznawcy nowej doktryny [Zdanowski 2004: 11].

Wahabizm posiadał również bardzo istotny $\mathrm{z}$ analitycznego punktu widzenia podtekst polityczny oraz społeczny. Potępienie wystawnego trybu życia oraz odejście od wszelkich innowacji miało charakter wyraźnie antyturecki oraz antyperski, co usprawiedliwiało tym samym saudyjskie dążenia ekspansjonistyczne. Natomiast oficjalne potępienie lichwiarstwa i bogactwa oraz nawoływanie do braterstwa i równości wszystkich Arabów były dla przedstawicieli niższych warstw społecznych perspektywą, za sprawą której wahabici zdobywali ich uznanie oraz poparcie. Co istotne, również z punktu widzenia lokalnych władz wahabizm mógł stanowić akceptowalną formę państwowości - zasada obowiązkowej jałmużny uprawomocniała bowiem pobieranie danin od miejscowej ludności, zaś zasada bezwarunkowego podporządkowania wobec przywódcy lub imama znacząco ugruntowywała pozycję władzy na poziomie lokalnym [Zdanowski 2004: 12-13].

Do fundamentów doktryny wahabickiej należy zaliczyć legitymizowanie przemocy celem narzucenia wiary innowiercom, jak również oficjalne przywrócenie instytucji szahidów (męczeństwa za wiarę oraz automatycznego zbawienia duszy bez oczekiwania na sąd ostateczny). Zgodnie z powyższym sens życia wahabity winien opierać się na bezustannej walce $z$ innowiercami i heretykami oraz na rozpowszechnianiu wiary muzułmańskiej. W nawiązaniu do współczesności można 
posłużyć się przykładem misjonarzy oraz filantropów wyjeżdżających do Bośni i Hercegowiny, Albanii, Malezji, Turcji oraz republik postradzieckich (szczególnie Rosji oraz państw Kaukazu), finansowanych przez ruch wahabicki na przełomie XX i XXI w. [Kobzarska-Bar 2014: 174-175].

\section{WSPÓŁCZESNE ZNACZENIE WAHABIZMU DLA ARABII SAUDYJSKIEJ}

Po dokonaniu charakterystyki na poziomie historycznym oraz doktrynalnym kolejny element analizy został oparty na ilustracji współczesnej roli wahabizmu. Jak zostało już wskazane we wcześniejszej części artykułu, państwowość Arabii Saudyjskiej zbudowano na dwóch współzależnych fundamentach - rodzinie Saudów (reprezentującej władzę świecką) oraz klanie al-Szajch (który przez bliskie pokrewieństwo z Muhammadem Ibn Abd al-Wahhabem uosabia wpływy religijne) [Kosta 2013: 133].

W Arabii Saudyjskiej znaczenie wahabizmu zdaje się być szczególnie widoczne na poziomie społecznym. Do najważniejszych „reform” ruchu zalicza się bowiem skrajną marginalizację kobiet, widoczną w ograniczaniu podstawowych praw w niemal wszystkich sferach życia społecznego (np. w kontekście swobody przemieszczania się, możliwości prowadzenia pojazdów [Schanzer, Miller 2012: 37-39], obecności w mediach czy też prawa do powszechnej edukacji). Co więcej, ideologiczna ekspansja wahabizmu objęła swoim zasięgiem wiele innych obszarów życia. W związku z powyższym można wskazać na takie elementy, jak: brak wolności religijnej (włącznie z niewahabickimi odłamami islamu) [Saudi Publications... 2005: 12], brak wolności politycznej (stabilne rządy Saudów to jednocześnie silna pozycja wahabitów), stosowanie własnego systemu kar (np. ścięcie głowy skazanym za zabójstwo czy też odcinanie rąk złodziejom), zakaz nadawania obywatelstwa osobom nienależącym do wspólnoty muzułmańskiej, jak również wiele obstrukcji związanych z paleniem tytoniu, muzyką oraz tańcem. W celu egzekwowania scharakteryzowanych wyżej zasad do życia powołany został tzw. Komitet Krzewienia Cnót i Zapobiegania Złu [Sindi 2004: 1-2]. Obok sprawowania kontroli nad sądownictwem oraz życiem religijnym w Arabii Saudyjskiej wahabici posiadają też dominującą pozycję w kształtowaniu państwowego systemu szkolnictwa. Reasumując, pomimo pewnych reform wahabicki establishment $\mathrm{w}$ dalszym ciągu sprawuje niekwestionowaną kontrolę nad życiem społecznym [Grabowski 2013: 72-79].

Warto też podkreślić, że królowie Arabii Saudyjskiej noszą tytuł Strażnika Dwóch Świętych Meczetów, co również wskazuje na ścisłą relację pomiędzy wymiarem religijnym oraz politycznym. Wystarczy przypomnieć, że mianowani przez króla następcy tronu potrzebują poparcia nie tylko rodziny Saudów, ale również islamskich teologów (tzw. ulemów, gdzie na szczycie hierarchii znajdują się członkowie rodziny Abd al-Wahhaba)².

2 Najwyższy z ulemów nazywany jest Wielkim Muftim. Przewodniczy on tzw. Radzie Starszych Ulemów, powołanej do życia w 1971 r. Wspomniana Rada składa się z 20 członków, którzy mianowani 
Dlatego też w wyniku religijnych zależności władza króla posiada obecnie ograniczony charakter. Co więcej, wszystkie akty prawne obowiązujące na terytorium Arabii Saudyjskiej muszą być zgodne z Koranem i sunną. Silna pozycja ulemów, posiadających wyłączne prawo do interpretacji świętych pism przyczynia się w rezultacie do sytuacji, w której władca nie może podejmować decyzji politycznych bez uwzględnienia opinii wahabitów [Imach 2015: 193-195].

Należy tu wyjaśnić, że na przestrzeni ostatnich lat wahabizm uległ też pewnym podziałom. Część saudyjskich duchownych za sprawą piastowania wysokich funkcji na dworze królewskim sprzeciwiała się dalszej radykalizacji wahabizmu (w obawie przed potencjalną destabilizacją państwa oraz utratą uprzywilejowanych pozycji). Jednocześnie wykrystalizowaniu uległa też grupa młodych i mniej wpływowych kaznodziejów, nawołująca do pierwotnych idei doktryny oraz kontestująca pozycję najwyższych przedstawicieli wahabizmu, zarzucając im upolitycznienie oraz sprzeniewierzenie się muzułmańskim wartościom. Innymi słowy duchowni znajdujący się na wyższym szczeblu hierarchii z jednej strony są bardziej zależni od króla, a w konsekwencji bardziej skłonni do akceptowania aktualnej polityki władz. Z drugiej zaś strony, ci niezwiązani z saudyjskimi elitami charakteryzują się zdecydowanie większą samodzielnością oraz radykalizmem w głoszonych przez siebie wartościach [Imach 2015: 192-195].

Na poziomie międzynarodowym wyznawcy wahabizmu również posiadają jasno określony kierunek ekspansji. Według May’a Darwicha [2014: 13], główne założenia doktryny wahabickiej pierwotnie były oparte na idei panislamizmu. Jednakże rewolucja w Iranie w 1979 r. wymusiła „geograficzną redukcję” dotychczasowych założeń, co w konsekwencji przyczyniło się do wykrystalizowania kolejnej idei przywództwa nad islamem sunnickim. Dążenia te również musiały zostać ograniczone w wyniku wydarzeń związanych z tzw. Arabską Wiosną oraz umocnieniem pozycji Bractwa Muzułmańskiego. W związku z powyższym obecny zakres ideologicznej tożsamości Arabii Saudyjskiej oparty jest na założeniach doktryny salaficko-wahabickiej, będącej radykalnym odłamem sunnizmu³. Uzupełniając niniejszy wątek, warto dodać, że rozwój wahabizmu wynika również z międzynarodowego przepływu sezonowych robotników, poszukujących pracy na terenie Arabii Saudyjskiej [Brataniec 2009: 166]. Uwarunkowania gospodarcze stanowią tym samym kolejny element, który determinuje obecne znaczenie wahabizmu.

Dążenie w kierunku polityczno-religijnej supremacji nad całą bądź przynajmniej określoną częścią społeczności muzułmańskiej posiada swoje uzasadnienie. Doktryna wahabicka zakłada bowiem, że jej wyznawcy zostali predestynowani do sprawowa-

są decyzją króla na czteroletnie kadencje. Do najważniejszych kompetencji Rady należy weryfikowanie zgodności królewskich dekretów z Koranem i sunną.

3 Sunnizm to największy odłam współczesnego islamu. W skład sunnizmu wchodzi kilka „nurtów”, między innymi nurt hanbalicki/wahabicki czy też salaficki. Pomimo doktrynalnej bliskości wskazuje się, że wahabizm jest bardziej rygorystyczną wersją islamu. Oba nurty należą do ruchów o charakterze reformatorskim, postulujących oczyszczenie islamu oraz powrót do pierwotnych wartości. 
nia niepodzielnego przywództwa w świecie muzułmańskim. Warto przypomnieć, że ideologie odwołujące się do arabskiego nacjonalizmu zaczęły zyskiwać na znaczeniu już pod koniec XIX w. Tego typu ruchy nawiązywały do postulatu współpracy i solidarności międzyarabskiej czy nawet do powołania panarabskich organizacji politycznych. Jednakże brak możliwości wypracowania wspólnego kierunku działań ostatecznie przekreślił realizację założeń panarabskich w tamtym okresie [Jamsheer 2014: 14].

Pomimo politycznych ograniczeń wizja arabskiej predestynacji pozostaje wciąż żywa w wielu kręgach społecznych Arabii Saudyjskiej. Wynika to przede wszystkim z obecnego poczucia wyższości oraz dumy narodowej. Półwysep Arabski był miejscem narodzin Proroka, to tu doświadczył on objawienia oraz to na tej ziemi podyktował Koran. Saudyjczycy nie uważają się więc za przedstawicieli religijnego ruchu o specyfice sekciarskiej. Wręcz przeciwnie, utożsamiają się z rolą depozytariuszy najwyższej formy objawienia bożego. To właśnie z tego założenia ma wynikać obowiązek narzucenia tej formy całej społeczności muzułmańskiej. Istnieć może bowiem wyłącznie jeden islam, a według Saudyjczyków to właśnie ich islam jest tym właściwym. Należy również podkreślić, że sojusz z al-Szajchami znacznie zwiększył prestiż Saudów. W przeciwieństwie do dynastii Haszymidów panującej obecnie w Jordanii czy też królów szarifickiego Maroka dynastia Saudów nie jest w stanie wykazać żadnego pokrewieństwa z Prorokiem. Pomimo sprawowania nadzoru nad świętymi miastami islamu Saudowie z historycznego punktu widzenia nie wywodzą się z wielkich rodów muzułmańskiej arystokracji. Tym samym swoista legitymizacja, jaką nadaje im sojusz z rodem al-Szajch, stanowi bardzo istotny element w kontekście budowania aktualnej pozycji politycznej w regionie Bliskiego Wschodu [Marchand 2004: 23, 29].

\section{SAUDYJSKI WAHABIZM A WSPÓŁCZESNY TERRORYZM}

Zaangażowanie Arabii Saudyjskiej na rzecz finansowania międzynarodowego terroryzmu stanowi współcześnie nad wyraz zawoalowaną oraz niejednoznaczną kwestię. W celu uporządkowania tego zagadnienia warto odwołać się do wydarzeń z lat 70. ubiegłego wieku. Arabia Saudyjska (obok Pakistanu i Stanów Zjednoczonych Ameryki) w sposób znaczący zaangażowała się bowiem w proces finansowania radykalnych ugrupowań, walczących podczas radzieckiej interwencji w Afganistanie (1979-1989). Jak pokazały kolejne lata, działania te przyczyniły się do uformowania jednej z najniebezpieczniejszych organizacji terrorystycznych na świecie-Al-Kaidy [Waterman 2014: 247]. Jej przywódca Osama bin Laden, po uzyskaniu wystarczających środków finansowych oraz upadku Związku Radzieckiego, za główny cel polityczny uznał wyrugowanie zachodnich wpływów z kręgu cywilizacji muzułmańskiej. Warto zaznaczyć, że do gwałtownej radykalizacji antyzachodniej retoryki Osamy bin Ladena przyczyniła się zgoda decydentów Arabii Saudyjskiej na rozlokowanie 
sił wojskowych Stanów Zjednoczonych Ameryki na Półwyspie Arabskim w ramach operacji „Pustynna Tarcza”, będącej wstępem do I wojny w Zatoce Perskiej [Marlowe 2001: 116]. Przywódca Al-Kaidy został również politycznie zmarginalizowany przez najwyższe kręgi Arabii Saudyjskiej, które w obawie przed radykalizmem jego organizacji oraz możliwym zagrożeniem dla własnej pozycji w państwie nie wyraziły zgody na wykorzystanie bojówek Al-Kaidy w celu obrony przed ewentualną agresją Iraku. To właśnie wówczas Osama bin Laden uznał rodzinę Saudów za odstępców od wiary oraz głównych wrogów cywilizacji muzułmańskiej (obecność wojsk niewiernych w pobliżu Medyny oraz Mekki została odebrana przez niego jako szczególne upokorzenie dla świata islamu) [Brachman 2009: 27-28]. Wskazuje się jednak, że dopiero wrześniowe ataki terrorystyczne na wieże World Trade Center oraz Pentagon w 2001 r. spowodowały rzeczywisty wzrost ,znaczenia” Al-Kaidy (podniesiono ją wówczas do rangi najgroźniejszej organizacji terrorystycznej na świecie, jak również pod pretekstem jej zwalczania dokonano dwóch interwencji zbrojnych - w Afganistanie oraz Iraku) [Kondrakiewicz 2008: 133-134]. Należy zatem stwierdzić, że polityka zagraniczna Arabii Saudyjskiej w drugiej połowie XX w. stanowiła jedno w podstawowych uwarunkowań, mających wpływ na wzrost znaczenia ugrupowań terrorystycznych na Bliskim Wschodzie.

Początek XXI wieku unaocznił dalsze zaangażowanie ruchu wahabickiego w kontekście wspierania ugrupowań terrorystycznych. Porażka talibów podczas interwencji Sojuszu Północnoatlantyckiego w 2001 roku w Afganistanie w niektórych kręgach saudyjskich teologów została odebrana bardzo negatywnie. Uważali oni bowiem, że rządy talibów w największym stopniu realizują zasady państwa opartego na doktrynie ruchu wahabickiego [Al-Rasheed 2011: 291-293]. To właśnie za sprawą doktrynalno-religijnej bliskości część wahabitów udzielało schronienia afgańskim bojownikom na terenie Arabii Saudyjskiej. Nie zmienił tego nawet negatywny stosunek króla, który zdawał sobie sprawę z faktu, że powyższy proces może znacząco obciążyć wizerunek Arabii Saudyjskiej, a tym samym utrudnić polityczne relacje z państwami trzecimi [Imach 2015: 192].

Współczesna aktywność polityczna Arabii Saudyjskiej w podobnym stopniu naznaczona jest nieoficjalnymi powiązaniami z ugrupowaniami reprezentującymi skrajne odłamy islamu. Co więcej, rodzina Saudów od lat jest zaangażowana w tzw. działalność charytatywną, ukierunkowaną na wspieranie swoich współwyznawców w pozostałych regionach świata (np. przez budowę meczetów czy też rozwój szkół teologicznych). Co istotne, pomimo ponadnarodowego charakteru pomocy, konsekwentnie pomijane są w tym przypadku wszystkie pozostałe doktryny islamu [Kepel 2003: 77]. O ile scharakteryzowane powyżej motywacje nie budzą poważnych zastrzeżeń, to kwestie przepływów finansowych oraz ich transparentność stanowią współcześnie przedmiot wielu ożywionych dyskusji i spekulacji. Część obserwatorów, dokonując analizy źródeł finansowania współczesnych ugrupowań terrorystycznych na Bliskim Wschodzie, w sposób jednoznaczny wskazuje bowiem na prominentnych przedstawicieli ruchu wahabickiego [Blanchard 2008: 4]. 
Za argument może posłużyć przykład księżniczki Hajfy Bint Fajsal, córki byłego króla Arabii Saudyjskiej oraz żony Bandara Ben Sultana, polityka pełniącego funkcję ambasadora Arabii Saudyjskiej w Stanach Zjednoczonych Ameryki w latach 1983-2005. Jak wynika z dostępnych dziś informacji, Hajfa Bint Fajsal udzielała bezinteresownej pomocy finansowej Omar'owi al-Bayoumi'emu - saudyjskiemu obywatelowi mieszkającemu w Stanach Zjednoczonych Ameryki. Mężczyzna okazał się być jednak powiązany z dwoma terrorystami (al-Mihdhar i al-Hazmi), którzy w późniejszym czasie uczestniczyli w zamachach z 11 września 2001 r. [Scott 2017: 132]. Księżniczka oraz jej mąż stanowczo dowodzili, iż nie mogli posiadać wiedzy na temat ostatecznych beneficjentów zorganizowanej przez nich pomocy. Po wrześniowych zamachach wiele osób zaczęło poddawać krytyce kwestię niewystarczających uregulowań w kontekście międzynarodowych przepływów finansowych. Nie dziwi zatem fakt, że brak dostatecznej kontroli ze strony saudyjskich władz nad przepływami gotówkowymi arabskiego establishmentu budzi współcześnie uzasadnione obawy o poziom ekonomicznej transparentności na najwyższych szczeblach tego państwa [Marchand 2004: 47-48].

Analogiczne powiązania można było dostrzec również w kontekście aktywności Państwa Islamskiego. Obrazują to poszczególne statystyki: od marca do lipca 2015 r. co najmniej dwa tysiące Saudyjczyków wyjechało do Syrii i Iraku w celu przyłączenia się do funkcjonujących tam radykalnych ugrupowań. Co więcej, liczba zatrzymanych osób podejrzanych o próbę takiego wyjazdu w okresie od listopada $2013 \mathrm{r}$. do lipca 2015 r. uległa niemal podwojeniu [McDowall 2015]. Wskazuje się również, że Arabia Saudyjska przez długi czas dostarczała syryjskiej opozycji uzbrojenie oraz zaopatrywała ją w środki finansowe. Należy w tym miejscu zauważyć, że większość dostaw trafiała ostatecznie w ręce skrajnych dżihadystów, zaś pomimo oficjalnego sprzeciwu saudyjskich decydentów wsparcie w dalszym ciągu było kontynuowane za pośrednictwem nieformalnych kanałów [Moniquet 2013: 12-13]. Dla salafickich ugrupowań w Syrii zaangażowanie Arabii Saudyjskiej stanowiło tym samym jedno z podstawowych źródeł logistyczno-finansowego wsparcia. Co ciekawe, część autorów utożsamia powstanie Państwa Islamskiego z ukonstytuowaniem Arabii Saudyjskiej w 1932 r., dostrzegając między tymi podmiotami wiele podobieństw o charakterze doktrynalnym [Dorsey 2016: 362-363].

Polityczno-religijne ambicje Arabii Saudyjskiej w stosunku do Państwa Islamskiego widoczne były przede wszystkim w polityce zagranicznej prowadzonej względem Syrii (Arabia Saudyjska w sposób wyraźny opowiadała się przeciwko rządom Baszara al-Asada). Nie należy jednak utożsamiać powyższej linii politycznej z dążeniem w kierunku demokratyzacji Syrii. Wręcz przeciwnie - w scenariuszu opartym na marginalizacji rządzącej klasy alawickiej Arabia Saudyjska pokłada głęboką nadzieję na przejęcie władzy przez dominujących w społeczeństwie Syrii przedstawicieli sunnizmu. Co więcej, Saudowie ograniczyliby wówczas wpływy szyickiego Iranu oraz Hezbollahu, co w dalszej kolejności otworzyłoby możliwość rozszerzenia wpływów wahabickich na poszczególne państwa Bliskiego Wschodu 
[Michalik 2014: 153]. Zakulisowe wspieranie struktur Państwa Islamskiego, mające na celu obalenie rządów Baszara al-Asada oraz całkowitą marginalizację szyitów w regionie, zdaje się tylko potwierdzać rewizjonistyczne dążenia Arabii Saudyjskiej [Atwan 2015: 212-213].

Wśród badaczy analizujących współczesne wydarzenia na Bliskim Wschodzie wyróżnić można opinię, iż salaficcy bojownicy Państwa Islamskiego zaczerpnęli swą polityczno-religijną inspirację z ukonstytuowanego w 1744 r. pierwszego państwa wahabickiego, co potwierdzać ma w ten sposób doktrynalną bliskość powyższych ruchów [Bunzel 2016: 1]. Ponadto w przemówieniach Abu Bakra al-Baghdadi'ego (pierwszego przywódcy Państwa Islamskiego) dostrzec można wiele nawiązań do myślicieli doktryny wahabickiej, co również świadczy o ideologicznym pokrewieństwie [Bunzel 2015: 10-11]. W powyższym kontekście wymowne znaczenie posiadają słowa prof. Ahmada Moussalli'ego [2009: 3], który skonstatował, iż wszyscy wahabici są salafitami, jednak nie wszyscy salafici to wahabici.

\section{ZAKOŃCZENIE}

Uwarunkowania religijne w kontekście regionu Bliskiego Wschodu należą do najważniejszych czynników kształtujących lokalną rzeczywistość polityczną, zaś Arabia Saudyjska oraz ruch wahabicki zdają się tylko potwierdzać powyższą tezę. Postulaty związane z powrotem do fundamentów islamu czy też uznaniem wszystkich Arabów za równych sobie nieprzypadkowo zyskały na Półwyspie Arabskim tak wielu zwolenników. Wahabizm, oprócz założeń nawiązujących do sfery teologicznej i gospodarczej, u swych źródeł posiadał również (czy wręcz przede wszystkim) silnie zaakcentowany podtekst polityczny. Z jednej strony ujmował muzułmańską wizję świata w kategoriach idei panarabskiej, z drugiej zaś charakteryzował się wymową antyturecką oraz antyperską. Co więcej, obowiązek bezwzględnego podporządkowania się panującemu przywódcy oraz przekonanie o konieczności poszerzania wspólnoty w ramach świętej wojny stanowiły polityczne narzędzia, dające pretekst do ekspansji względem całego Półwyspu Arabskiego [Małachowski 2012: 246-247]. Współcześnie wahabizm jest postrzegany przez pryzmat społeczno-religijnej nietolerancji oraz finansowych związków z radykalnymi ugrupowaniami islamistycznymi. Pomimo tak poważnych podejrzeń powyższe zagadnienia ciągle nie doczekały się adekwatnej reakcji ze strony społeczności międzynarodowej. Pozostaje więc wyłącznie w sferze domniemań, czy obecna sytuacja może wynikać z polityczno-ekonomicznej kalkulacji oraz polityki podwójnych standardów, stosowanej przez współczesne mocarstwa. 


\section{BIBLIOGRAFIA}

Al-Rasheed, M. 2011. Historia Arabii Saudyjskiej, Książka i Wiedza, Warszawa.

Atwan, A.B. 2015. Islamic State. The Digital Caliphate, Saqi Books, London.

Bakalarz, A. 2007. Próby reform politycznych w Arabii Saudyjskiej a opozycja ze strony islamistów, „Krakowskie Studia Międzynarodowe", nr 3, s. 9-28.

Blanchard, C.M. 2008. The Islamic Traditions of Wahhabism and Salafiya, https://fas.org/sgp/crs/misc/ RS21695.pdf (dostęp: 18.12.2016).

Brataniec, K. 2009. Zachód i islam. Dylematy relacji, Krakowskie Towarzystwo Edukacyjne, Kraków.

Bunzel, C. 2016. From Paper State to Caliphate: The Ideology of the Islamic State, „Analysis Paper”, nr 19, https://www.brookings.edu/wp-content/uploads/2016/06/The-ideology-of-the-Islamic-State. pdf (dostęp: 18.12.2016).

Bunzel, C. 2016. The Kingdom and the Caliphate. Duel of the Islamic States, Carnegie Endowment for International Peace, Washington.

Czaputowicz, J. 2014. Mapa współczesnego realizmu: realizm klasyczny, neorealizm, realizm neoklasyczny, [w:] Teorie realizmu w nauce o stosunkach międzynarodowych. Założenia i zastosowania badawcze, E. Haliżak, J. Czaputowicz (red.), Wydawnictwo Rambler, Warszawa.

Darwich, M. 2014. The Ontological (In)security of Similarity: Wahhabism versus Islamism in Saudi Foreign Policy, „GIGA Working Papers”, nr 263, https://www.giga-hamburg.de/de/system/files/publications/ wp-263-online.pdf (dostęp: 18.12.2016).

Delong-Bas, N.J. 2004. Wahhabi Islam: From Revival and Reform to Global Jihad, Oxford University Press, New York.

Dorsey, J.M. 2016. Saudi Arabia And Iran: The Battle For Hegemony That The Kingdom Cannot Win, „Przegląd Strategiczny”, nr 9, s. 357-373. DOI: https://doi.org/10.14746/ps.2016.1.25.

Fryzeł, T. 1974. Panarabizm. Źródta i rozwój idei, Wydawnictwo „Nauka dla Wszystkich”, Kraków.

Grabowski, W. 2013. Fundamentalizm muzulmański na Bliskim Wschodzie, Wydawnictwo Uniwersytetu Gdańskiego, Gdańsk.

Imach, M. 2015. Problemy religijne Arabii Saudyjskiej, „Teologia i Człowiek”, vol. 32, s. 173-197. DOI: http://dx.doi.org/10.12775/TiCz.2015.027.

Jamsheer, H.A. 2014. Państwo i społeczeństwo w świecie arabskim: Niepowodzenie wzorców nacjonalistycznego i islamistycznego, [w:] Bliski Wschód w XXI wieku. Polityka - Społeczeństwo - Zmiana, J. Marszałek-Kawa, J. Piechowiak-Lamparska (red.), Wydawnictwo Adam Marszałek, Toruń.

Kaczmarski, M. 2015. Realizm neoklasyczny, [w:] Teorie i podejścia badawcze w nauce o stosunkach międzynarodowych, R. Zięba, S. Bieleń, J. Zając (red.), Wydział Dziennikarstwa i Nauk Politycznych Uniwersytetu Warszawskiego, Warszawa.

Kepel, G. 2003. Święta wojna. Ekspansja i upadek fundamentalizmu muzulmańskiego, Wydawnictwo Akademickie DIALOG, Warszawa.

Kobzarska-Bar, B. 2014. Fundamentalizm religijny muzulmańskich organizacji terrorystycznych a stan zagrożenia w Europie, „Rocznik Bezpieczeństwa Międzynarodowego”, nr 8/1, s. 167-182. DOI: http://dx.doi.org/10.34862/rbm.2014.1.13.

Kosta, R.A. 2013. Konflikty - kolonializm - fundamentalizm w przestrzeni bliskowschodniej, Wydawnictwo ECE, Torun.

Małachowski, G.Ł. 2012. Następstwo tronu w Królestwie Arabii Saudyjskiej, [w:] Zmiany polityczne w państwach arabskich. Wybrane zagadnienia ustrojowe, A. Rothert, J. Szymanek, A. Zięba (red.), Dom Wydawniczy ELIPSA, Warszawa.

Marchand, S. 2004. Arabia Saudyjska. Zagrożenie, Wydawnictwo Akademickie DIALOG, Warszawa.

McDowall, A. 2015. Inside the Saudi prison that's home to new wave of jihadis, „Reuters” 06.07.2015, http:// www.reuters.com/article/us-saudi-security-prison-idUSKCNOPG1CO20150706 (dostęp: 18.12.2016). 
Michalik, D. 2014. Potencjały państw zaangażowanych w konflikt syryjski w początkach kryzysu, [w:] Fale Tunisami. Kontestacja arabska w latach 2010-2013, R. Potocki, M. Piskorski, W. Hładkiewicz (red.), Europejskie Centrum Analiz Geopolitycznych, Warszawa.

Moniquet, C. 2013. The Involvement Of Salafism/Wahhabism In The Support And Supply Of Arms To Rebel Groups Around The World, Publications Office, Brussels.

Moussalli, A. 2009. Wahhabism, Salafism and Islamism: Who Is The Enemy?, Beirut, http://conflictsforum. org/briefings/Wahhabism-Salafism-and-Islamism.pdf (dostęp: 18.12.2016).

Saudi Publications on Hate Ideology Invade American Mosques, 2005, https://freedomhouse.org/sites/ default/files/inline_images/Saudi\%20Publications\%20on\%20Hate\%20Ideology $\% 20$ Invade $\% 20$ American\%20Mosques.pdf (dostęp: 18.12.2016).

Schanzer, J., Miller, S. 2012. Facebook Fatwa. Saudi Clerics, Wahhabi Islam and Social Media, FDD Press, Washington.

Scott, P.D. 2017. The American Deep State. Big Money, Big Oil, And The Struggle For U.S. Democracy, Rowman \& Littlefield, Lanham-Boulder-New York-London.

Sindi, A.M. 2004. Britain and the Rise of Wahhabism and the House of Saud, „Kana'an Electronic Bulletin", nr 4/361, s. $1-9$.

Sozek, J. 2005. Osama bin Laden's Global Islamism and Wahhabi Islam, „McGill Journal of Middle East Studies", nr 8, https://www.mcgill.ca/mes/files/mes/MJMESSozek.pdf (dostęp: 18.12.2016).

Waterman, D. 2014. Saudi Wahhabi Imperialism in Pakistan: History, Legacy, Contemporary Representations and Debates, „Societal Studies”, nr 6/2, s. 242-258. DOI: https://doi.org/10.13165/SMS-146-2-02.

Zdanowski, J. 2004. Arabia Saudyjska, Wydawnictwo Naukowe ASKON, Warszawa.

\section{IMPACT OF WAHHABISM ON THE SOCIO-POLITICAL POSITION OF SAUDI ARABIA}

Abstract: The aim of the paper is to analyze the role of the Wahhabism for the contemporary position of Saudi Arabia in the social and political dimension. In connection with the above, three research hypotheses will be verified in this paper. The first assumes that the weakening position of the Ottoman Empire at the turn of the $19^{\text {th }}$ and $20^{\text {th }}$ century, and the alliance with the Saud family were the main elements that influenced the development of the Wahhabi movement in Saudi Arabia. Secondly, as a result of close links with the Saudi family, the Wahhabi movement today plays a decisive role in creating the socio-political position of Saudi Arabia. Thirdly, Wahhabism supports the development of Salafi terrorist organizations because of their religious and political proximity.

The main conclusion can be summarized in the statement that the Wahhabi movement plays a key role in creating the social life of Saudi Arabia and seeks religious expansion in the Middle East, including through connections with Salafi terrorist organizations. The article also presents the genesis of Wahhabism and its doctrinal principles.

To present the methodological workshop used in this paper, we should point to the case study method, by which the links between Arab Wahhabism and Salafi terrorist organizations have been characterized (in relation to Al-Qaeda and Islamic State). In order to proper illustrate the impact of Wahhabism on the socio-political position of Saudi Arabia, premises derived from the current of neoclassical realism have been presented.

Keywords: Wahhabism, Saudi Arabia, terrorism, Islam 


\section{BIOGRAM}

Michal Harkot, magister, doktorant na Wydziale Politologii i Dziennikarstwa Uniwersytetu Marii Curie-Skłodowskiej w Lublinie na kierunku Nauki o polityce. Zainteresowania naukowe: region Bliskiego Wschodu, terroryzm, historia XX wieku. Kontakt e-mail: harkot.michal92@gmail.com. 